\title{
Karma and Sin: Foundation of Moral Philosophy in Theravāda Buddhism and Eastern Orthodoxy
}

\author{
Indunil Philip Shantha W.G. ${ }^{\text {a }}$, Svetlana Rykova ${ }^{\text {b }}$ \\ Zhejiang University, Hangzhou, China. \\ a 0617344@zju.edu.cn \\ b11604076@zju.edu.cn
}

Keywords: Buddhism; Orthodoxy; Karma; Sin, moral philosophy.

\begin{abstract}
This article attempts to define the concept of Sin in Eastern Orthodoxy and karma in Theravāda Buddhism, comparing the foundation of moral philosophy. Both concepts are the base of the ethical code. In Buddhism, karma is explained as volitional action (cetanā), not all actions have results. Karma can be of two varieties. Actions that based upon desires (lobha) hatred (dosa) and delusion (moha), which are mental states that impure the mind and manifest in unwholesome actions. Actions driven by generosity (alobha), goodwill (adosa), non-delusion (amoha) are manifest in wholesome actions and In Orthodoxy, one meaning of Sin, for that person have private responsibility, is a personal action that hurt oneself when he destroy the natural law of harmony and beauty according to that God created the whole world and that already inherent to this world. According to Theravāda Buddhism karma explicit as optimistic view of life giving responsibility to human to decide goodness and badness.
\end{abstract}

\section{Introduction}

Ability to be moral appropriates to every human being, however, the understanding about forming and development of this ability, understanding what it depends on, varies from different cultures and religious traditions. In this paper the authors would like to consider how this question is explained according to the two main religions in the world - Buddhism (in its initial tradition - Theravāda Buddhism) and Christianity (in one of its main denominations, Eastern Orthodoxy).

\section{Sin in Orthodoxy}

There are three main meanings of Sin [1] in Eastern Orthodoxy (that is different from understanding of Sin in other Christian denominations):

\subsection{Original or Ancestral Sin}

There were certain damaging/degenerating of original nature of Adam and Eve, that have happened after they decided to break God's commandment, and realized their will to be free from God and His rules, that caused the consequences which they felt down from Heaven and come to Earth, where their innocent nature was changed in next way: instead of eternal life their life became limited and finished with death (become mortal), instead of eternal youth, beauty and health they had experience of being sick and aging (become perishable), they lost the invulnerability to sufferings, they start feeling suffering and pain, different passions appeared. And this damaging nature of primogenitors inherited by all fallen men as their descendant. So that's why nature of all born people, the same as nature of all living beings and inanimate nature, became vulnerable: became mortal, perishable, and liable to influence of passions. At the same time we cannot say that our nature was innocent and only because of the sin of our forefathers, we now should be born and have experience of suffering and death. No, even this is not our personal fault, our nature is the same as Adam and Eve, and were we them at that time, we chose the same things, as we also have this desire to know, what does it mean, to replace God's position, to live without Source of Life. That really means that all of us are infected with the virus of proud. We want to be the first, to be independent, to have 
experience of life without God. So under this original sin we will understand this damaging nature of all people.

\subsection{Family Sin}

In this case sin is considered as a personal defect of one's nature that one inherits from the family. According to this idea, not only physicals features person can inherit from his ancestors, but also the tendency to follow some moral and spiritual rules or tendency to destroy them (i.e., as desire to lie, to steal, to envy, etc.). If no one can change own nature which is consequences of original sin; family sin, even it is not one's personal fall but it is certain negative precondition that came from his ancestors, one can somehow realized and take under control, but can't eliminate at all. Like seeds of weeds that are already under the ground, that can prevent farmer from having good harvest, somehow he can control their appearance by cultivating and giving nutrition to cultivated plants only and trying to eradicate the weeds that never can disappear totally. From this point of view, every person is responsible for those moral and spiritual characteristics that he will develop in himself and that his posterity will inherit.

\subsection{Actual or Personal Sin}

There are three main characteristics of God in Orthodoxy, which are Good, Love and Beauty. Everything that exists (includes a human with his physical, mental, spiritual parts) were created according to this characteristics, what means everything were organized not only with an aim to be good and usable, but at the same time everything is full of harmony and beauty and follow the inner perfect law. And when person do something that destroy this harmony and contradict with this natural law than inherent to this world, when a person destroys the world around him, his body, or his inner world, all of these is called sinful action or sin; and negative, painful results of these destroying actions itself are punishment for such person (that means that there is no God who punishes person for his sins, person hurt himself by his wrong behavior; as God is Good and only Good and doesn't have a desire to hurt anyone).

According to Eastern Orthodoxy, the main aim of personal life is Salvation (in other words: the acquisition of the Holy Spirit of God; possibility to be united with Him in eternity; returning to God). And it is also returning to conditions as our forefather (Adam and Eve) had before falling: to immortality, eternity, and invulnerability to sufferings. And to realize this aim, a person should purify his nature from these three types of sins, to become as perfect and pure as God himself and in this way to get an opportunity to return to Him. And if second and third types of sin somehow can be under persons control if he makes a conscious decision, during all of his life to follow the Christ's commandments, never commit Mortal sin [2], every second of life try to live consciously, try to protect own inner life from sinful things that are mentioned in Gospel (i.e., anger, nursing a grievance, lie, hypocrisy, deceiving, envy and blaming others, rancor, voluptuousness, etc.) not only in his behavior but also in his thinking that is more difficult (sometimes almost impossible to prevent yourself from wrong thinking, in this case, it needs repentance and sincere desire to fight with own imperfections, and it also needs every day prayers to God and asking for His forgiveness).

At the same time no one person can avoid committing sinful things (even if in real life one can stop himself from doing bad, but it is almost impossible, even for saints, to protect own mind from negative destroying, sinful, thinking), and this weakness humanity has because of damaging original nature (as we explained in Part One) that is impossible to heal by person himself and lead to necessity of someone who can cure it - to the Savior [3] (Jesus Crist who inside of Himself cured this damaging nature and gave a chance to all of us to have a new conscious birth in Him (to describe how it happens, it takes more detailed explanation) and gave us a chance to purify own nature) [4].

So as we can see, this necessity to be good, to be moral, to avoid sin, is natural for any person, because it helps him to stop hurting, destroying himself by his own deeds. And that gives him a chance to live a more beautiful, happy, and harmonious life. And what is more important, such life, according the God's commandments, leads to purification, that sure needs a lot of personal effort from one side, and God's help from other side, and that can help a person to reach life aim - Salvation. 


\section{Karma in Theravāda Buddhism}

The word karma literally means "action" or "doing" (Pāli: Kamma, or Sanskrit: Karma). But in the Buddhist theory, karma has a specific meaning. Not all actions, which means all 'volitional action', actions, which spring from the intention (Pali: cetanā) of an unenlightened being[5]. Many people misuse it as result of karma. In Buddhist terminology, the word "karma" is divided into two. According to it's fruit or result (Pali: kamma-phala or kamma viphāka). The fruit of wholesome karma called as puñña (merit) and fruit of unwholesome karma called as papa (demerit). The Buddhist theory of karma and result (karmaphala) is fundamental of Buddhist philosophy, because it provides a coherent model of the functioning of the beings (satta) and world (loka), in forms of the doctrinal explanations of karma theory. Karma is also associated with different conditions, and has various reasons. The Visuddhimagga states that "the karma that is the condition for the fruit. In the canonical texts of Theravāda tradition explained about result of karma, which is complicated, and karma what we did in whole life not always appear in this life. That's why this topic is said not to think too much or judge at once.

There is no single cause for fruits. Ignorance (avijjā) or not knowing is the chief cause of karma. Dependent on ignorance arise karmic activities (avijjā paccayā saṇkhārā). All good deeds of a worldling (puthujjana), though associated with the three wholesome roots of generosity, goodwill and knowledge/non delusion are nevertheless regarded as karma because the two roots of ignorance and craving are dormant in worldling. Buddhaghosa comments on karma of Buddhist causality: "Here there is no single or multiple fruit of any kind from a single cause, nor a single fruit from multiple causes, but only multiple fruit from multiple causes. For the Blessed One employs one representative cause and fruit when it is suitable for the sake of elegance in instruction and to suit the idiosyncrasies of those susceptible to being taught." [6]

When conditions are suitable, the karmic consequence may emerge. Wholesome karma is possible to change or destroy the result of unwholesome Karma or sin. It is based upon the principle of freedom of the will. According to Mahākammavibhanga-sutta and Culakamavibhanga-sutta in Majjhima nikāya[7], karma has potential to changes the situation of one's own life by doing good karma. Mahākammavibhanga-sutta shows some of the complexities of karma and its results. Beginning with a strange view expressed by a confused wanderer and a confused answer given by a bhikkhu (Buddhist monk), the Buddha then gives his Great Exposition of Karma, which is based upon four types of people: (1). The evildoer who goes to hell, (2). The evildoer who goes to heaven, (3). The good man who goes to heaven, and, (4). The good man who goes to hell. Buddha explains his Great Exposition of Karma in which he shows that notions of invariability like "the evildoer goes to hell" are much too simple. The minds of people are complex and they make many different kinds of karma even in one lifetime, some of which may influence the last moment when karma is made before death, which in turn is the basis for the next life.

In Culakammavibhanga-sutta is also called Subha-sutta, which was given to Subha by Buddha. Subha asked Buddha what differentiates human beings[8]: (1). Short lived and long lived. (2). Diseased and healthy. (3). Ugly and beautiful. (4). Powerless and powerful. (5). Poor and rich. (6). Low born and high born. (7). Ignorant and Intelligent. This sutra gives specific examples of the fruits of karma, good and evil, based on the layman notion of good begets good, evil begets evil. Buddha's advice to his disciples was to practice virtues (sila), everyone to follow the moral life (dhamma) as embodied in eightfold path, in order to get rid of samsara circle. All the practices of Buddhism base on virtue or moral conduct, which is considered as doing good karma in life. Human life is base on morals, understandings of good and bad actions. Eightfold path divided into three parts; sila (morality), samādhi (concentration) and paññā (wisdom).

\section{The Concept of Sin in Buddhism}

Chattopadya states, As Buddhism does not believe in any personal God or any Supreme Being, the word pāpa, or sin stands for the evil elements that defile the mind and have a deadening effect on the psyche making it difficult for its upliftment. In the Theravāda tradition, the mind (citta) is considered to be the most important factor in the determination of the moral quality of an action [9]. Dhammapada says, All that we are the result of what we have thought: it is founded on our thoughts; 
it is made up of our thoughts[10]. Therefore, merit is interconnected with the notions of goodness; in the same way demerit is interconnected with badness.

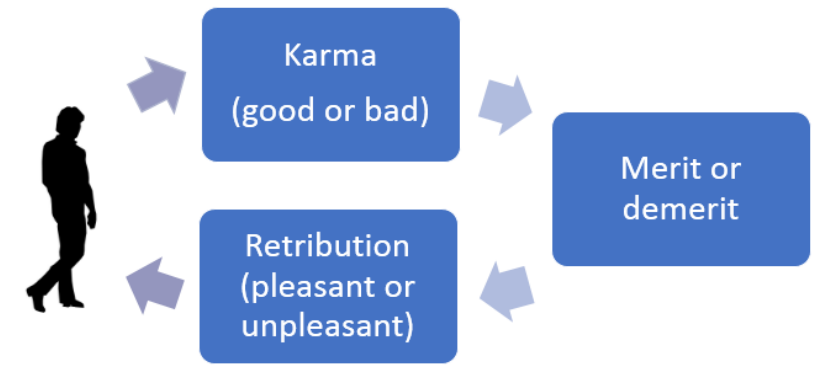

Fig. 1 The same way demerit is interconnected with badness.

Merit / demerit and it's retributions to individual. Based on Spiro [11]. This diagram gives us to clear understanding of karma, merit / demerit and influence to someone's life.

\section{Conclusion}

In Orthodoxy, sinful human's nature that caused their suffering basically begins with three reasons. Those are, damaging of original nature that people inherit from Adam and Eve; sinful behavior, vices, of previous members of the generation (family sin) that influence the progeny; person's own behavior and thinking, destroying natural laws of the world, that hurt the person by his own hands. In Theravāda Buddhism, karma based upon moral philosophy, whereby suffering is the inevitable consequence of desire, hatred, and ignorance which is known as defilements (kleshās). Both concepts are involving with moral philosophy. Both are affiliate with relationship between the actions and the results, and necessity to improve person's nature by doing good actions and avoid badness. In Theravāda Buddhism, result of action attribute to human power, we have to be responsible for our karma (moral) to be freed from suffering. In Orthodoxy, we have to "to be born in Christ" (which means, through the christening to heal damaging, sinful, nature), that give us a chance (in case if we take a decision to the end of our life strictly follow Gospel's commandments and promise not to commit sin again) to purify ourselves and get salvation. Experience of life in material world (that give us opportunity to know what life without God is) and realizing own sinful nature and impossibility to enjoy and avoid suffering, and be happy by ourselves, separated from God, leading a person to idea of necessity to have a reconnection with God. In Buddhism one should purify negative karma to understand the ultimate truth of suffering to liberate the circle of samsara. Theory of karma is based primarily upon the earliest discourses attributed to Buddha, which is preserved in Theravāda Pāli canon (pitaka). From the foregoing analysis, it is clear that Theravāda teaching on Karma and Orthodox Sin are directly related to the moral philosophy that is involved with in the moral and immoral character of an individual.

\section{References}

[1]. Osipov Alexey, The official website of the professor of the Moscow Theological Academy, Osipov Alexei Ilyich, Section: audio lectures "Sins and Passions", lectures for (2016-2017). Electronic resource. Information on: alexey-osipov.ru/audio/grekhi-i-strasti/

[2]. Varnava (Belyaev N.), Fundamentals of the art of holiness (1922-1928). Vol. 1. N. Novgorod: Publishing House of the Brotherhood in the name of St. Prince Alexander Nevsky (1995), p. 472.

[3]. Paisius Sviatogorec, The words. Vol. 5. Moscow, Publishing house: Sviataya gora, (2008), p. 683. Information on: https://azbyka.ru/otechnik/Paisij_Svjatogorets/strasti-i-dobrodeteli-slovatom5/

[4]. Ignatius Brianchaninov. Ascetic experiences. Vol. 1. Moscow, Publishing house of Sretensky monastery, (2010), p. 413. 
[5]. Visuddhimagga, The Path of Purification, trans. Bhikku Ñāṇamoli, Buddhist Publication Society, Kandy, (1991), p.553.

[6]. Anguttara Nikāya. The Book of the Gradual Sayings, tr F. L. Woodward \& E. M. Hare, 1932-6, 5, iii, p. 415

[7]. Majjhima Nikāya, the Middle Length Sayings of the Buddha, trans. I.B. Horner, Pali Text Society, London, (1959), ii , p.135-136.

[8]. Culakammavibhanga Sutta, Majjhima Nikaya No. 135. I.B. Horner (trans.), The Book of Middle Length Sayings, (1954, Pali Text Society.)

[9]. Madhumita Chattopad, ya, Sin (Buddhism), Buddhism and Jainism, editors: K.T.S Sarao,Jeffery D. Long, Edition, Springer, (2017).

[10]. Manopubbangamā dhammā manosețthā manomayā-Dhammapada, Yamakavagga,verse 1. In Buddhist Legends, tr E. W. Burlinghame, Harvard Oriental Series, (1921), reprinted by Pali Text Society

[11]. Spiro, Melford E, Buddhism and society: a great tradition and its Burmese vicissitudes (2 ed.), Berkeley u.a.: University of California Press, (1982). 